\title{
The construction of buildings which interfere with third-party rights and the risk of injunctions and claims for damages
}

\author{
Received (in revised form): 8th July, 2005
}

\section{Andrew Francis}

is a barrister in practice at Serle Court Chambers, Lincoln's Inn. He has a specialist Chancery practice which includes the law of restrictive covenants and rights of light. He is the author of the leading textbook on the former and the co-author of the leading textbook on the latter subject.

\begin{abstract}
Developers and their agents (lawyers, architects, surveyors and planning consultants) need to be aware of the risks that accompany development projects where that development infringes third-party rights. The third-party rights under discussion are rights under restrictive covenants and easements. The former are obligations which restrict the use of freehold land and the latter are legal interests in favour of third parties, such as rights of way, rights of support for land and buildings and rights of light. Rights of light and restrictive covenants are given prominence in this paper in view of the recent decisions in the courts which have considered them. The ultimate risk for developers is that an infringing development (eg a building or structure) may be the subject of an Order of the Court which requires the developer to pull down all or part of it.
\end{abstract}

\section{Keywords:}

building, injunction, light, covenant, damages

\section{TERMINOLOGY}

This paper does not deal with detailed law, but for the reader who is not a lawyer there are some terms used which may require explanation.

These are 'injunction' which is an Order of the Court stopping something from being done ('prohibitory') or requiring something to be done ('mandatory').

\section{EXAMPLES TO BE USED}

The first example is a fairly common one of an extension to a residential building which infringed a restrictive covenant and rights of light, causing measurable loss to the party who had the benefit of that covenant. ${ }^{1}$ The second example is one of a major inner-city redevelopment where rights of light were being infringed. 
Each of the examples given above has attracted the attention of the courts in recent months. The first example is based on the facts of Deakins $v$ Hookings ${ }^{2}$ and Mortimer $v$ Bailey $^{3}$ and the second is based on those in Midtown v City of London Real Property Co. ${ }^{4}$

\section{QUESTIONS WHICH ARISE}

These are:

- At what point does the risk of an injunction arise?

- How can such a risk be avoided or lessened?

- What is good practice for developers?

Note that this paper does not discuss the position under the planning laws. It is important for developers and their advisers to understand that the planning laws touch upon different areas of law and raise issues which are not material in the civil law under discussion. It should be appreciated that the fact that planning consent has been granted does not render the development immune from action in the civil courts. The paper does not deal with section 237 of the Town \& Country Planning Act 1990 and the right of local planning authorities and those deriving title under them to extinguish third-party rights such as easements and covenants affecting land which that authority has acquired or appropriated for planning purposes. This is a highly technical area of law and space does not permit its treatment here.

\section{BACKGROUND}

Three cases show what can happen.

\section{Deakins $v$ Hookings 5}

In this case the claim was for interference with the light enjoyed by 2 Ashbourne Terrace in London SW19 (Wimbledon) as a result of the erection by the neighbour of an extension to her property, 3 Ashbourne Terrace. By the time the proceedings were issued the extension was up and was occupied. It was found by the court that the interference with light to the claimant's rooms was substantial. The method of assessment was the conventional one in rights of light claims adopting the one lumen at table level standard, or 0.2 per cent of the whole sky. The fact that some of the claimant's rooms were badly lit made the effect of the extension worse. The court ordered the cutting back of part of the extension.

\section{Mortimer v Bailey ${ }^{6}$}

The claimants in this case had the benefit of a restrictive covenant which allowed them to protect their property (at Ainderby Steeple near Northallerton, North Yorkshire) against the property next door which was owned by the defendants. The defendants never obtained the consent of the claimants to an extension which they constructed. The effect of that extension was 'horrendous' because it reduced the available light and severely altered the aspect or view from the main room of the claimant's property (the kitchen) and caused a loss of sunlight on winter afternoons. 
The Court of Appeal upheld the trial judge's order that the extension must be removed and the defendants must restore their building to its former state. The warning of Jacob LJ in this case is of importance to those who try to 'skate over' covenants or ignore valid objections. He said: 'Where there is doubt as to whether a restrictive covenant applies or whether consent under a restrictive covenant is being unreasonably withheld, the prudent party will get the matter sorted out before starting building... If he takes a chance, then it will require very strong circumstances where, if the chance having been taken and lost, an injunction will be withheld.'

\section{Midtown $v$ CLRP $\mathrm{CO}^{7}$}

In this case the claimants, who were both landlord and tenant of an office block in Fetter Lane, London EC4, sought to prevent by injunction part of the large-scale redevelopment by the defendant of land off New Fetter Lane, known as the New Street Square site. The claimants had established rights of light over the site and it was clear that the interference with those rights of light was substantial and thus actionable. The judge considered the argument that in modern offices the use of electric light and the fact that such lighting dispenses with the need to rely on natural light can be the basis for dismissing a claim for interference with light based on the conventional tests and the 0.2 per cent sky factor, referred to above in the analysis of Deakins $v$ Hookings, but did not accept that argument in the case before him. The judge refused the application on five stated grounds which included the oppression to the defendant if it was prevented from carrying out a 'worthwhile and beneficial' development. The case is now going to be heard in early 2006 on the question of the claimants' rights to damages in lieu of an injunction.

\section{Discretionary remedies}

\section{PRINCIPLES}

What principles can be discerned from these cases? In general terms, the wider principle is founded upon the fact that an injunction is a discretionary remedy and that the court will examine all the surrounding facts and circumstances when considering whether or not to grant an order in the form of an injunction. Likewise, the court may decide not to grant an injunction but order the defendant to pay damages instead; this too is a discretionary remedy. This is what the court ordered in Midtown $v$ CLRP Co. ${ }^{8}$ In addition, and crucially in many cases, delay in enforcing rights is fatal to the ability of persuading a court to grant an injunction and damages in lieu. The knowledge of the claimant is therefore highly relevant and if the developer (or his agents) has kept the neighbours fully informed of the proposed development and its possible impact (but not to the extent of advising them as to their rights, which the neighbour can find out for himself), the harder it will be for the neighbour to obtain an injunction once the development of which he has had full notice is under way. 


\section{A TIME CHART}

The best way in which the principles can be explained is by a time chart which maps the progress of a typical development and its significant stages.

\section{Phase 1}

Post acquisition. Project at pre-planning stage and confidential to owners and agents. Funding obtained.

\section{Phase 2}

Planning application stage and notification by the Local Planning Authority to adjoining owners. Objections received. Consideration of application and consequential planning stages, appeal, calling in etc. Grant of planning consent and no subsequent challenge by judicial review. At both this stage and at phases 3 and 4 below there should be meetings and letters to involve neighbouring owners in the development with a neighbourly attitude shown by the developer. There may have to be agreement over crane oversailing rights and the resolution of issues such as scaffold overhangs, access and the abatement of dust etc with the usual health and safety statement to all neighbours.

\section{Phase 3}

Post-planning stages. Placing of demolition and building contracts and all necessary consents obtained, eg highway stopping up orders. Compliance with any planning conditions such as entry into section 106 agreements. Possible post-planning objections from adjoining owners on the footing that now the development may be a 'reality' there is recourse to legal rights.

\section{Phase 4}

Site clearance. Ground preparation. Environmental remediation.

\section{Phase 5}

Construction (through all stages) and topping out.

\section{Phase 6}

Fitting out and final fixing and completion.

\section{Phase 7}

Marketing (if not pre-sold or pre-let) and occupation.

It is well known that all these seven phases may take years to complete; however, as will be seen below, the risks are greatest and the time span is least when the construction process is underway. 


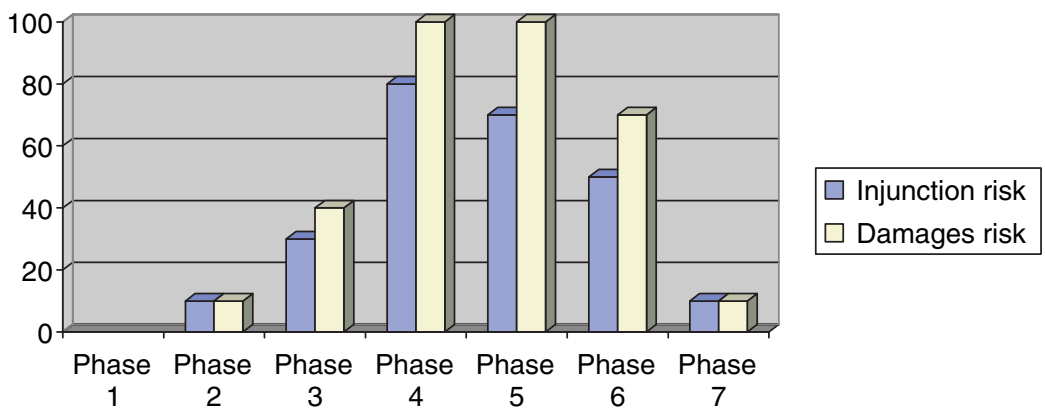

Figure 1: The assessment of risk

\section{RISKS}

The assessment of risk can be seen in graphical form in Figure 1. The vertical axis is expressed as a percentage (maximum of 100 per cent) of the risk of either an injunction or damages in lieu being awarded at each phase of the development which is infringing third-party rights. It should be obvious that the risks are greatest during the earlier rather than the later phases. Phases 3-5 are probably the most risky in terms of a claim being brought to stop the development which infringes rights, thereafter the risk subsides.

Figure 1 is, of course, a very crude analysis of the risks and no diagram can express the fact that in each case much will turn on the individual facts and circumstances which will all go to determine whether, as a matter of discretion, the court will grant the injunction or not. Likewise, the discretion to award damages in lieu will be affected by the facts of each case. But it is noteworthy (as can be seen from Figure 1) that the risk of damages being awarded in lieu may increase at times when the risk of the injunction being awarded decreases. This is because the court may decide that it is oppressive to stop the development and preferable to award damages in lieu at the stage when the development is complete or nearly so. But it would be a mistake for developers and their agents to think that the neighbouring owners' rights always can be bought out. The above-mentioned result in the Mortimer case (an order to pull the extension down even though complete) is an example which proves the exception to the 'rule' that the risk of an injunction at the later phases of construction may be less than a 10 per cent risk.

One final point which can be made about risk relates to damages. The courts in recent years have adopted the measure of damages (in order to compensate the claimant) which looks at the unlawful profit made by the wrongdoer as opposed to looking only at the loss to the victim. This means that damages claims for interference with rights in the nature of covenants and easements (as well as trespass to land and airspace) can be assessed by reference to a percentage of the net profit to be made or already made by the defendant. This may be a very high percentage or a low one depending on the facts of the case. ${ }^{9}$ There is no automatic 'one-third' of net value or profit. 


\section{LESSENING OR AVOIDING RISKS}

The role of the legal adviser is crucial and this paper cannot deal with all the aspects of the legal adviser's role and all the legal issues that may have to be addressed. A summary of the ways in which the risks of an injunction can be lessened or removed has been listed as follows.

- Always ensure that the legal adviser has all the necessary facts and that he and his agents have inspected the site.

- The legal adviser must be able to ask the right questions and this means full cooperation with him in respect of development plans.

\section{Reducing or avoiding} risk
- The early assessment of risk is important. For example, if there are buildings fronting the development site which look as if they have been there for about 15-17 years and may be about to acquire rights of light (after 20 years' enjoyment of light through the apertures in place) the advisers must consider whether a Light Obstruction Notice (registrable against the building which is enjoying the light) should be registered. These Notices are registered in the Local Land Charges Register against the titles to the buildings which might be able to claim rights of light over the development site. This is why the legal adviser must search in that register against the adjoining titles and not just in respect of the development site's title.

- Good neighbourly conduct and keeping the neighbouring owners and occupiers informed of the proposed development at an early stage is vital. Do not rely on the planning process to do this. The more information the developer gives out with regard to the details of the new building and the timing of various stages the better. It is equally important for those who are being consulted to respond to the invitations to meetings and to answer letters and e-mails. The same is true if the consultees want to open a dialogue with the developer. In the Midtown case (above), the failure of the adjoining owners and claimants to respond to letters and invitations to discuss the right of light issue raised by the development was one factor which the Judge held against the exercise of the discretion to grant an injunction to stop part of the development. The other reason why consultation with neighbours is important is because the court may be reluctant to grant an injunction to a person who has been fully aware of the development and should have been alert to his rights but has chosen not to stop the infringement. $^{10}$

- Persuade the neighbouring owner to accept money in exchange for the giving up of the right to stop the development. If this can be done in open correspondence the claimant probably will not obtain an injunction as he has openly indicated that all he wants is money. ${ }^{11}$

- If there is an issue over third-party rights such as covenants and rights of light get these issues opened up early. Deal with the legal advisers to the neighbours on an open basis and ask them how these rights (assuming they exist without any doubt as to their enforceability) are going to be dealt with. 
- Be realistic in negotiations to settle claims and to pay or receive release fees. $^{12}$

- If necessary go to the Lands Tribunal and ask the Tribunal either to modify or discharge covenants. This cannot be done with easements and other third-party rights. ${ }^{13}$

- If necessary, go to court to ask for an order that the rights infringed cannot be enforced by an injunction, leaving the defendants with those rights with their remedy in damages. This may be a last resort and the court will not make such an order unless the justice of the case is clearly in the claimant's favour. ${ }^{14}$

- If possible, insure under a title indemnity policy.

Finally, there is always the possibility that the neighbour will delay to the point that the risk becomes negligible (after the occupation of the building), although prudent developers always will try to ensure that the issue is dealt with before the building is finished. Funders, purchasers and tenants invariably will want third-party rights 'squared up' before they will fund, purchase or take a lease.

\section{CONCLUSION - GOOD PRACTICE}

The best way of explaining what is good practice is shown in the previous paragraph. The three 'Cs' are at the heart of good practice, these are:

\section{Good practice}

- Communication

- Cooperation

- Critical analysis.

In terms of the first two words there should be no problem in identifying what can be done by way of communication and cooperation with the adjoining owners to reduce or remove the risks of injunction. As to critical analysis, this means the developer and his advisers must ask themselves the question 'what risks are there in terms of third-party rights?' and then determine how these risks can be dealt with in a realistic way at the earliest possible stage.

(C) Andrew Francis 2005

\section{Author's Note}

The writer accepts no responsibility for any legal views expressed in this paper. The reader must always take his own advice on any matter where it is required and this paper is no substitute for that.

The use of the word 'he' or 'his' is not gender-specific.

\section{References}

Bickford-Smith, S. and Francis, A. (2000) Rights of Light, The Modern Law, Jordans, Bristol.

Francis, A. (2005) Restrictive Covenants and Freehold Land, A Practitioner's Guide, 2nd edn, Jordans, Bristol. 


\section{Note}

(1) The law on whether someone has the benefit of a restrictive covenant (not being party to the actual agreement imposing it) is very complex. The Court of Appeal recently looked at this issue in Crest Nicholson v McAllister [2004] EWCA Civ 410. In this paper it has been assumed that the party claiming the right to enforce the covenant actually can prove that he has the right to do so.

(2) [1994] 1 EGLR 190.

(3) [2004] EWCA Civ 1514; Court of Appeal.

(4) [2005] EWHC $33 \mathrm{Ch}$; Peter Smith J.

(5) [1994] 1 EGLR 191.

(6) [2004] EWCA Civ 1514

(7) [2005] EWHC $33 \mathrm{Ch}$.

(8) The jurisdiction to order damages in lieu of an injunction is statutory, but the way in which the court decides whether or not to award such damages is found in an old case concerning nuisance caused by the vibration of the defendant's generators in Shelfer $v$ City of London Electric Lighting Co [1895] 1 Ch 287. The 'good working rule' set out by the court in that case guided the judge in Midtown. The factors applicable are (a) when the injury to the claimant's legal rights is small; (b) where the injury is capable of being estimated in money; (c) where a small money payment would be compensation; and (d) where it would be oppressive to grant an injunction. The obvious point is that once a building is up (or substantially so) the greater the argument that it would be oppressive to order it to be pulled down. The same is true if the proposed development is not yet up but would be 'worthwhile and beneficial', as the development in Midtown was described by the judge in that case. The site of the dispute in Shelfer (Shelfer, the claimant, was the tenant of a public house called 'The Waterman's Arms') is now part of the former Bankside Power Station, now the home of Tate Modern.

(9) See the Amec decision referred to in note 12 below. See also the analysis of recent cases in Francis (2005: Chapter 15, para. 15.36/7). For the technical ways in which rights of light damages may be assessed see Ref. 1, in particular the very useful Chapter 12 written by Elizabeth de Burgh Sidley.

(10) Gafford v Graham [1998] 77 P\&CR 73 is the leading recent case and it has been considered in cases such as Mortimer $v$ Bailey (above). In all cases the question of delay may or may not be fatal to the claim for an injunction and or damages in lieu. Extreme delay with the requisite knowledge of what is going on may prevent the claimant from getting any remedy at all, as was made plain by the Court of Appeal in Gafford $v$ Graham. But, as can be seen in Mortimer v Bailey, there was never an indication that the claimants would accept money in return for the building staying up, and it may be that in that case the question of damages in lieu may not have been pressed as far as it ought to have been at the trial.

(11) See Gafford v Graham (note 10).

(12) The principles and conclusion set out in Amec Developments v Jury's Hotel Management UK Ltd [2001] 82 P\&CR 286 should be compulsory reading for all advisers engaging in negotiations to release rights. The statement by the judge at para. 35(n) of the judgment that 'In any negotiation science and rationality gets one only so far. At the end of the day the deal has to feel right' is an essential 'benchmark' and the slavish adherence in all cases to the 'Stokes' 33.3 per cent which some advisers seem to adopt must be resisted.

(13) The detail of this jurisdiction is beyond the scope of this paper, see Ref. 2.

(14) As was done in the case of a major redevelopment to be carried out under Public/Private Partnership funding in Greenwich Healthcare NHS Trust $v$ London \& Quadrant Housing Trust \& Others [1998] 1 WLR 1749. 